\title{
PUBLISHER CORRECTION
}

\section{Publisher Correction: Augmented $\mathrm{CD}^{+}{ }^{+}$T-cell and humoral responses after repeated annual influenza vaccination with the same vaccine component $\mathrm{A} / \mathrm{H} 1 \mathrm{~N} 1 \mathrm{pdm} 09$ over 5 years}

Mai-Chi Trieu ${ }^{1,2}$, Fan Zhou $^{1,2}$, Sarah Larteley Lartey ${ }^{1,2}$, Saranya Sridhar ${ }^{3,6}$, Siri Mjaaland ${ }^{2,4}$ and Rebecca Jane Cox ${ }^{1,2,5}$

npj Vaccines (2018)3:45; doi:10.1038/s41541-018-0081-5

Correction to: npj Vaccines https://doi.org/10.1038/s41541-0180069-1, Published online 14 August 2018

In the original published version of this Article, the text for the "Editorial Summary" was mistakenly incorporated at the end of the abstract. The HTML and PDF versions of the paper have been corrected.

Open Access This article is licensed under a Creative Commons Attribution 4.0 International License, which permits use, sharing, adaptation, distribution and reproduction in any medium or format, as long as you give appropriate credit to the original author(s) and the source, provide a link to the Creative Commons license, and indicate if changes were made. The images or other third party material in this article are included in the article's Creative Commons license, unless indicated otherwise in a credit line to the material. If material is not included in the article's Creative Commons license and your intended use is not permitted by statutory regulation or exceeds the permitted use, you will need to obtain permission directly from the copyright holder. To view a copy of this license, visit http://creativecommons. org/licenses/by/4.0/.

(c) The Author(s) 2018

\footnotetext{
${ }^{1}$ The Influenza Centre, Department of Clinical Science, University of Bergen, Bergen, Norway; ${ }^{2}$ K.G. Jebsen Centre for Influenza Vaccine Research, Department of Clinical Science, University of Bergen, Bergen, Norway; ${ }^{3}$ Jenner Institute, University of Oxford, Oxford, UK; ${ }^{4}$ Department of Infectious Disease Immunology, Norwegian Institute of Public Health, Oslo, Norway and ${ }^{5}$ Department of Research and Development, Haukeland University Hospital, Bergen, Norway

Correspondence: M-C. Trieu (chi.trieu@uib.no) or Rebecca Jane. Cox (rebecca.cox@uib.no)

${ }^{6}$ Present address: Sanofi Pasteur, 1541 Avenue Marcel Mérieux, 69280 Marcy I'Etoile, France
}

Published online: 11 September 2018 